\title{
SENSORY ANALYSIS AND CHEMICAL COMPOSITION OF 'BOURBON' COFFEES CULTIVATED IN DIFFERENT ENVIRONMENTS
}

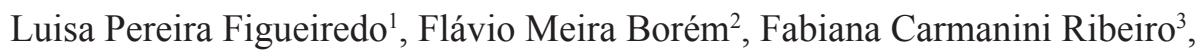 \\ Gerson Silva Giomo ${ }^{4}$, Marcelo Ribeiro Malta ${ }^{5}$, José Henrique da Silva Taveira ${ }^{6}$
}

(Received: march 16, 2017; accepted: july 10, 2017)

\begin{abstract}
Given the growing participation and appreciation of specialty coffees in the international market, coupled to the intrinsic quality of cultivar Bourbon for the production of differentiated coffees and the environmental diversity of Brazil, this study was conducted, with the objective to evaluate how the interaction between 'Bourbon' genotypes and different environments affect the sensory quality of coffees, besides relating the chemical composition (trigoneline, 5-CQA and caffeine) of beans with their sensory profile. Four Arabica coffee genotypes were evaluated: one of them is widely grown in Brazil (Mundo Novo) and three belong to the group of cultivar Bourbon. The genotypes were evaluated in a field experiment, in Lavras, MG; Santo Antônio do Amparo, MG and São Sebastião da Grama, SP. Thelatter was the most promising environment for the production of specialty coffees. Genotypes Yellow Bourbon IAC J9 and Yellow Bourbon/SSP were the most suitable for the production of specialty coffees. Regardless of culture environment, the genotype Yellow Bourbon/CM is not suitable for the production of specialty coffees. Caffeine content enabled coffee differentiation regarding beverage quality. Coffees with superior quality have lower caffeine contents. The content of 5-CQAallowed to differentiate environments.
\end{abstract}

Index terms: Specialty Coffees,genotypes, yellow bourbon, multidimensional scaling.

\section{ANÁLISE SENSORIAL E COMPOSIÇÃO QUÍMICA DE CAFÉS 'BOURBON’ CULTIVADOS EM DIFERENTES AMBIENTES}

RESUMO: Diante da crescente participação e valorização dos cafés especiais no mercado internacional, associadas à qualidade intrínseca da cultivar Bourbon para a produção de cafés diferenciados e à diversidade ambiental do Brasil, realizou-se o presente trabalho, com o objetivo de avaliar como a interação entre genótipos de 'Bourbon' e diferentes ambientes afetam a qualidade sensorial dos cafés, bem como relacionar a composição química (trigonelina, 5-ACQ e cafeína) dos grãos com a sua expressão sensorial. Foram avaliados quatro genótipos de café arábica, sendo um amplamente cultivado no Brasil (Mundo Novo) e três pertencentes ao grupo da cultivar Bourbon. Os genótipos foram avaliados na forma de experimento em campo, nos municípios de Lavras, MG; Santo Antônio do Amparo, MG e São Sebastião da Grama, SP. Este último foi o ambiente mais promissor para a produção de cafés especiais. Os genótipos Bourbon Amarelo IAC J9 e Bourbon Amarelo/ Origem SSP foram os mais indicados para a produção de cafés de especiais. Independente do ambiente de cultivo, o genótipo Bourbon Amarelo origem CM não é indicado para a produção de cafés especiais. O conteúdo de cafeína possibilitou a discriminação de cafés quanto à qualidade de bebida. Cafés com qualidade superior têm menores teores de cafeína. O conteúdo de 5-ACQ permitiu discriminar ambientes.

Termos para indexação: Cafés especiais, genótipos, Bourbon amarelo, escalonamento muldimensional.

\section{INTRODUCTION}

Although the commodity coffee segment represents the largest share of all coffee exported worldwide, the specialty coffee segment has achieved great prominence in the international market. The increasing participation of this segment justifies various incentives to improve quality, both in farming practices and in research and technological innovation. Coffee producing countries increasingly show interest in understanding environmental, genetic and technological factors affecting quality (AVELINO et al., 2005). Brazil is traditionally known as a supplier of large quantities of common and low-cost coffees, and has favorable conditions to increase its share in the specialty coffee market, given the diversity of its coffee plantations and the high technological level of coffee production(GIOMO; BORÉM, 2011).

\footnotetext{
${ }^{1}$ Federal University of Lavras/UFLA-Food Science Department/DCA-Cx. P. 3037 - 37.200-000 - Lavras - MG - luisa.figueiredo@dca.ufla.br ${ }^{2}$ Federal University of Lavras/UFLA- Engineering Department/DEG - Cx. P. 3037 - 37.200-000 - Lavras - MG - flavioborem@deg.ufla.br ${ }^{3}$ Brasília University/UNB - Agronomy and Veterinary Medicine Department - 70910-970 - Brasília - DF - fabianacarmanini@yahoo.com.br ${ }^{4}$ Agronomic Institute/IAC - 13.020-970 - Campinas - SP - gsgiomo@iac.sp.gov.br ${ }^{5}$ Agricultural Research Company of Minas Gerais/EPAMIG - Campus UFLA - Cx.P. 176 - 37.200-000 - Lavras - MG marcelormalta@gmail.com

${ }^{6}$ State University of Goiás/UEG - 75920-000 - Santa Helena de Goiás - GO - henriquetaveira@yahoo.com.br
}

Coffee Science, Lavras, v. 13, n. 1, p. 122 - 131, jan./mar. 2018 
In general, any Coffea Arabica L. cultivar has the potential to produce high-quality coffees. However, it has been found that different tastes and smells occur more frequently in some cultivars. Cultivar Bourbon has world-renowned intrinsic qualities due to its sensory characteristics. It is used for the production of specialty coffees in different regions of the world. However, different genotypes are described as Bourbon, resulting in the occurrence of crops with totally different characteristics and named Bourbon. In addition to the phenotypic and agronomic variability, Ferreira et al. (2012), Figueiredo et al. (2013) and Figueiredo et al. (2015) evaluated the interaction between Bourbon genotypes and different environments and observed that there are Bourbon genotypes more adapted to the production of quality coffee for each environment.

Coffee is a product whose quality is differently expressed as a function of the planting site. It is directly influenced by environmental aspects, both natural and human (AVELINO et al., 2005; BERTRAND et al., 2006; VILLARREAL et al., 2009; CAMARGO, 2010; ALVES et al., 2011). In Brazil, there are numerous coffeeproducing regions with different edaphoclimatic characteristics, which are essential for beverage flavor.

Several studies were conducted in order to correlate the levels of some chemical compounds, such as caffeine, trigoneline and chlorogenic acids, with species differentiation, the assessment of degree of roasting, quality and functional properties of coffee (DESSALEGN et al., 2008; PERRONE et al., 2008; DUARTE et al., 2010; RIBEIRO et al., 2011; KY et al., 2013).In other studies, it was sought to relate these chemical compounds as potential descriptors for quality expression of coffee genotypes in different environments. Avelino et al. (2005) differentiated the environments Santa Maria de Dota e Orosi, in Costa Rica, through the quantification of chemical compounds caffeine, trigoneline, chlorogenic acids and sucrose, justifying the sensory differences among these coffees. The composition of chlorogenic acids and especially fatty acids allowed the differentiation of environments Naranjal, Paraguaicito and Rosario, located in Colombia (BERTRAND et al., 2008).

It is observed that, despite the great potential of cultivar Bourbon for the production of specialty coffees, it is not well understood if there is a genotype capable of producing highquality coffees, regardless of the environment.
On the other hand, it is believed that it is possible to find one or more Bourbon genotypes suitable for the production of specialty coffees in different environments and that its chemical composition can be used as an indicator of that capacity.In this context, this study was conducted in order to assess how the interaction between Bourbon genotypes and different environments affects the sensory quality of coffees, as well as relate the chemical composition of the beans with their sensory quality.

\section{MATERIALS AND METHODS}

Four genotypes of Coffea Arabica L. (Table 1) were grown in experimental field plots since 2005 in the southern region of the state of Minas Gerais and in the region of Mogiana in the state of São Paulo. Both regions are highlighted for their production of Arabica coffee on a large scale. The distinct edaphoclimatic conditions of these important Brazilian coffee producing regions were represented in this study, and their main characteristics are shown in Table 2. The genotypes were chosen for this research from a group of 14 Bourbon genotypes, which were 11 Bourbon genotypes and 3 commercial cultivars. Then, 01 commercial cultivar widely grown in various regions (G1) and 03 Bourbon genotypes (G2, G3 and G4) were picked. In addition, this selection was based on a previous research Figueiredo (2010) and preliminary dataset of the present study. The agronomic characteristics of the studied genotypes can be observed in Ferreira et al. (2013).

\section{Coffee harvest and processing}

Coffee fruits were handpicked (collected in 2010 and 2011) and selectively harvested when the fruits were completely mature to guarantee the complete uniformity of the material from the different parcels. Then, the coffee fruits were peeled to obtain the pulped coffee. Drying was carried out in patio drying immediately after processing according to the method of Borém, Andrade and Isquieredo (2014), until coffee beans were at the level of $11 \%$ (w.b) moisture content.

\section{Sample preparation}

After drying, the samples were packed in paper bags and covered with plastics bags, identified and stored in chambers at a controlled temperature of $18^{\circ} \mathrm{C}$ for 60 days. 
TABLE 1 - Studied genotypes and environments and their codes $^{\mathrm{a}}$.

\begin{tabular}{ll}
\hline \multicolumn{1}{c}{ Environments } & \multicolumn{1}{c}{ Genotypes } \\
\hline A1 = Lavras & G1 $=$ Mundo Novo IAC 502/9 \\
A2 = São Sebastião da Grama & G2 = Yellow Bourbon IAC J9 \\
A3 = Santo Antônio do Amparo & G3 = Yellow Bourbon /Origin SSP \\
& G4 = Yellow Bourbon /Origin CM $^{\mathrm{b}}$ \\
\hline
\end{tabular}

$\overline{{ }^{a}} \mathrm{~A} 1, \mathrm{~A} 2, \mathrm{~A} 3, \mathrm{G} 1, \mathrm{G} 2, \mathrm{G} 3 \mathrm{e}$ G4 = codification of the genotypes and environments used in the discussion of the results.

${ }^{\mathrm{b}} \mathrm{SSP}=$ São Sebastião do Paraíso, MG; CM = Carmo de Minas, MG.

TABLE 2 - Geographic region, climatic variables and characterization of the three studied environments.

\begin{tabular}{lccc}
\hline \multicolumn{1}{c}{ Municipality } & Lavras & São Sebastião da Grama & Santo Antônio do Amparo \\
\hline \multicolumn{1}{c}{ Region } & Southern Minas Gerais & Mogiana Paulista & Southern Minas Gerais \\
\hline Altitude & $919 \mathrm{~m}$ & $1300 \mathrm{~m}$ & $1050 \mathrm{~m}$ \\
Mean temperature & $20.4^{\circ} \mathrm{C}$ & $20^{\circ} \mathrm{C}$ & $19.9^{\circ} \mathrm{C}$ \\
Mean annual precipitation & $1460 \mathrm{~mm}$ & $1560 \mathrm{~mm}$ & $1700 \mathrm{~mm}$ \\
Latitude & $21^{\circ} 14^{\prime} 43^{\prime \prime} \mathrm{S}$ & $21^{\circ} 44^{\prime} 50^{\prime \prime} \mathrm{S}$ & $20^{\circ} 56^{\prime} 47^{\prime \prime} \mathrm{S}$ \\
Longitude & $44^{\circ} 59^{\prime} 59^{\prime \prime} \mathrm{W}$ & $46^{\circ} 55^{\prime} 33^{\prime \prime} \mathrm{W}$ & $44^{\circ} 55^{\prime} 08^{\prime \prime} \mathrm{W}$ \\
Soil type & Clayey Oxisol & Clayey Oxisol & Clayey Oxisol \\
\hline
\end{tabular}

Then, the samples were hulled and the defects were removed in order to standardize the samples and minimize interferences unrelated to the genetic material or the environment. Chemical analysis and roasting were performed in beans retained on screen 16 and higher (16, 17 and 18/64 inches).

\section{Roasting and sensory evaluation}

All procedures were performed according to the protocol described by the Specialty Coffee Association - SCA. Ten sensory attributes were evaluated by a panel of six trained judges and scored on a scale of 10 points according to SCA(LINGLE, 2011). The sensory attributes included the aroma, uniformity, absence of injuries, sweetness, flavor, acidity, body, balance, completion and overall impression. The final sensory grade was generated from the sum of all of the evaluated attributes. For each evaluation, five cups of coffee representing each genotype were evaluated, with one session of sensory analysis for each repetition and a total of three repetitions. Each environment was evaluated separately. In addition to the final grade obtained from the sensory evaluation, the attributes of aroma, acidity, body and flavor were also analyzed statistically in order to complement the analysis, considering that these are the main attributes responsible for distinguishing the different sensory profiles of the coffee.

\section{Caffeine, trigonelline and 5-caffeoylquinic acid (5-CQA)}

Extractions of compounds were performed in duplicate for each of the three replicates according to (FIGUEIREDO et al., 2013). The concentrations of caffeine, trigonelline and 5-CQA were determined simultaneously using highperformance liquid chromatography (HPLC). Therefore, the system operated with a Rheodyne injection valve (model 77251), with a loop fixed at $20 \mu \mathrm{L}$ and a data processor (Shimadzu). Areverse-phase C18 column $(5 \mu \mathrm{m}, 250 \mathrm{~mm}$ x $4.6 \mathrm{~mm}$,Shim-pack CLC-ODS (M), Shimadzu) wasused, with a 4- $\mu \mathrm{m}$ pre-column. Elution was isocratic with a mobile phase consisting of methanol:aceticacid:water (30: 0.5:69.5; v:v:v), flow of $1 \mathrm{~mL} / \mathrm{min}$ at $22{ }^{\circ} \mathrm{C}$. The concentration of the compounds was determined by the ratio among peak areas of caffeine, trigonelline and 5-CQA of the sample and the respective standards of known concentrations. The final contents of caffeine, trigoneline and 5- CQA were given in percentage of dry matter (\% DM). 


\section{Statistical analysis}

Four Arabica coffee genotypes were evaluated in three production environments. The three experiments were conducted in a randomized block design (RBD), with three replications in the field and plots consisting of ten plants. Multidimensional geometric representation of the data was performed using multidimensional scaling (MDS) (COX; COX, 2001) with the statistical software R (R CORE TEAM, 2012). Qualitative or quantitative relationships between the data correspond to geometric relationships in this representation.

\section{RESULTS AND DISCUSSION}

\section{Sensory quality and chemical composition: effect of genotypes and environments}

The mean values of sensory attributes, final sensory score and chemical compounds in relation to genotypes, environments, and interactions between genotypes and environments are presented in Table 3.

Table 4 shows the dissimilarity matrix among the twelve points of the interaction between genotypes and environments $\left(A_{x} G_{y}\right.$ for sensory variables of the transformed data matrix. It is possible to observe that lower values indicate more similar points (AxGy), while higher values indicate dissimilarity between points (AxGy).

Figure 1 shows the biplot with multidimensional scaling of 4 genotypes and 3 environments for sensory attributes (acidity, fragrance, flavor and body) and final sensory score, besides the stress function generated for the purpose of checking the quality of the adjustment MDS provided by the reduction in variables. In the representation, the distances between the points are directly related to dissimilarities between them (Figure 1A). The stress function was equal to 0.02 , indicating a high-quality setting (Figure 1B). This fact allows to state that the relationship between sensory attributes and environments can be synthesized by these variables, represented in predictive axes.

The points $A 3 \mathrm{G} 2$ and $\mathrm{A} 2 \mathrm{G} 3$; $\mathrm{A} 2 \mathrm{G} 1$ and A1G3, for example, are the most similar to each other, as shown in Table 4, of dissimilarity measures. Given this proximity between the points, it is possible to visualize the formation of groups genotypes $\chi$ environments: group I, formed by the points $\mathrm{A} 3 \mathrm{G} 1, \mathrm{~A} 1 \mathrm{G} 1, \mathrm{~A} 2 \mathrm{G} 4, \mathrm{~A} 1 \mathrm{G} 4$ and
A3G4; group II, by points $\mathrm{A} 3 \mathrm{G} 3$ and $\mathrm{A} 1 \mathrm{G} 2$ and group III, by points A2G2, A1G3, A3G2, A2G3 and $\mathrm{A} 2 \mathrm{G} 1$. It is important to emphasize that group III is that with the greatest proximity, that is, the greatest similarity between their points.

It is observed that coffees grouped to the left of the biplot (group I) showed lower intensity of the attributes fragrance, flavor and acidity, when compared to coffees grouped on the right (group III) (Figure 1A). This grouping also has lower sensory scores (below 80 points), when compared to group III (Table 3). All genotypes that showed scores above 80 have the potential for the production of specialty coffees, especially those with a score higher than 81 points.

The attributes flavor, acidity and fragrance were the most decisive for coffee differentiation. On the other hand, in this study, the attribute body little contributed to group differentiation (Figure 1A). However, it was responsible for approaching or distancing points within the groups formed in relation to the vertical axis. The points allocated to group I were those which suffered the greatest interference of the variable body. This can be observed by analyzing the points $\mathrm{A} 3 \mathrm{G} 1$ and A1G4. Both points have values of acidity, flavor and final sensory score very similar and differed for the attributes fragrance, and especially body.

From the groups formed, it is possible to observe that the genotype Yellow Bourbon (G4) did not express well, from a sensory point of view. In addition, regardless the environment studied, it was always allocated in group I and presented high similarity to the genotypes allocated in this group. Therefore, although the intrinsic quality of Bourbon is globally known and widely used for the production of specialty coffees in various regions of the world (FIGUEIREDO et al., 2013), it is observed that there is variability in beverage quality among the Bourbon genotypes studied. Variations found in flavor, acidity and fragrance indicate that not all Bourbon genotypes have the same potential for the production of specialty coffees. These results corroborate those of Ferreira et al. (2012) and Figueiredo et al. (2013), who detected differences in the potential to produce quality coffees among different Bourbon genotypes.

The environment São Sebastião da Grama (A2) stood out, compared to the others. In this environment, all genotypes, except G4, showed higher intensity of the sensory attributes acidity, flavor and fragrance and comparatively higher 
TABLE 3 - Sensory evaluation and average levels of 5-CQA, trigoneline and caffeine of beans from different Arabica coffee genotypes and environments.

\begin{tabular}{ccccccccc}
\hline genotype/environment & fragrance & flavor & acidity & body & final & 5-CQA (\%) & trigoneline (\%) & caffeine (\%) \\
\hline G1 & 7.25 & 7.11 & 7.25 & 7.37 & 80.38 & 4.30 & 0.88 & $1.14 \mathrm{~b}$ \\
G2 & 7.60 & 7.39 & 7.38 & 7.37 & 81.61 & 4.51 & 0.82 & $1.06 \mathrm{a}$ \\
G3 & 7.58 & 7.44 & 7.43 & 7.33 & 81.76 & 4.63 & 0.86 & $1.11 \mathrm{~b}$ \\
G4 & 7.26 & 7.07 & 7.15 & 7.17 & 79.87 & 4.76 & 0.90 & $1.14 \mathrm{~b}$ \\
\hline A1 & 7.36 & 7.20 & 7.22 & 7.24 & 80.59 & 4.36 & 0.85 & 1.13 \\
A2 & 7.52 & 7.35 & 7.37 & 7.36 & 81.42 & 4.52 & 0.86 & 1.08 \\
A3 & 7.38 & 7.22 & 7.32 & 7.33 & 80.70 & 4.75 & 0.88 & 1.12 \\
\hline
\end{tabular}

TABLE 4 - Dissimilarity matrix among the twelve points (interactions genotypes $\chi$ environments, $A_{x} G_{y)}$ for sensory variables.

\begin{tabular}{cccccccccccccc}
\hline & A1G1 & A1G2 & A1G3 & A1G4 & A2G1 & A2G2 & A2G3 & A2G4 & A3G1 & A3G2 & A3G3 & A3G4 \\
\hline A1G1 & 0.000 & 1.403 & 2.460 & 0.355 & 2.398 & 2.257 & 2.780 & 0.191 & 0.236 & 2.659 & 1.531 & 0.498 \\
A1G2 & 1.403 & 0.000 & 1.080 & 1.187 & 1.019 & 0.867 & 1.393 & 1.234 & 1.435 & 1.277 & 0.181 & 0.990 \\
A1G3 & 2.460 & 1.080 & 0.000 & 2.244 & 0.155 & 0.234 & 0.332 & 2.295 & 2.477 & 0.221 & 0.939 & 2.050 \\
A1G4 & 0.355 & 1.187 & 2.244 & 0.000 & 2.192 & 2.037 & 2.559 & 0.302 & 0.528 & 2.449 & 1.315 & 0.338 \\
A2G1 & 2.398 & 1.019 & 0.155 & 2.192 & 0.000 & 0.237 & 0.413 & 2.232 & 2.414 & 0.273 & 0.878 & 1.986 \\
A2G2 & 2.257 & 0.867 & 0.234 & 2.037 & 0.237 & 0.000 & 0.531 & 2.090 & 2.274 & 0.428 & 0.740 & 1.849 \\
A2G3 & 2.780 & 1.393 & 0.332 & 2.559 & 0.413 & 0.531 & 0.000 & 2.615 & 2.797 & 0.157 & 1.258 & 2.371 \\
A2G4 & 0.191 & 1.234 & 2.295 & 0.302 & 2.232 & 2.090 & 2.615 & 0.000 & 0.275 & 2.494 & 1.365 & 0.346 \\
A3G1 & 0.236 & 1.435 & 2.477 & 0.528 & 2.414 & 2.274 & 2.797 & 0.275 & 0.000 & 2.672 & 1.565 & 0.614 \\
A3G2 & 2.659 & 1.277 & 0.221 & 2.449 & 0.273 & 0.428 & 0.157 & 2.494 & 2.672 & 0.000 & 1.139 & 2.251 \\
A3G3 & 1.531 & 0.181 & 0.939 & 1.315 & 0.878 & 0.740 & 1.258 & 1.365 & 1.565 & 1.139 & 0.000 & 1.114 \\
A3G4 & 0.498 & 0.990 & 2.050 & 0.338 & 1.986 & 1.849 & 2.371 & 0.346 & 0.614 & 2.251 & 1.114 & 0.000 \\
\hline G1= Mundo Novo IAC 502/9, G2= YellowBourbonIAC J9, G3=Yellow Bourbon/SSP, G4= Yellow Bourbon/CM, A1= Lavras, A2= São Sebastião da Grama,
\end{tabular}

final sensory scores, always placed in group III. Thus, when the environment is favorable to the production of specialty coffees, it is suggested that the selection or indication of genotypes for cultivation could prioritize the identification and restriction of genotypes improper for quality. The three studied environments stand out for the production of Arabica coffee in large scale. However, according to Alves et al. (2011), even in areas suitable for the production of good-quality coffees, climate diversity can cause variations in beverage characteristics. According to Dal Molin et al. (2008), changes in climate conditions interfere in the formation and maturation of fruits, changing their intrinsic characteristics, which can allow different beverage qualities.

Environment A2 is that with the highest altitude $(1,300 \mathrm{~m})$. In many studies, there are reports that the rise in altitude is related to the increase in beverage quality (GUYOT et al., 1996; DECAZY et al., 2003; AVELINO et al., 2005; BERTRAND et al., 2006). Decazy et al. (2003) evaluated the quality of coffees grown in six regions of Honduras and concluded that higher altitudes and rainfall lower than $1,500 \mathrm{~mm}$ were favorable for sensory quality. Avelino et al.(2005) related high altitudes with higher-quality coffees, located in two terroirs of Costa Rica, Orosi and Santa Maria de Dota. Guyot et al.(1996) also reported an improvement in beverage quality from higher altitudes in Guatemala.

The points A1G1 (Lavras/Mundo Novo) and A3G1 (Santo Antônio do Amparo/Mundo Novo) presented the greatest dissimilarity in relation to the group of coffees with higher sensory 

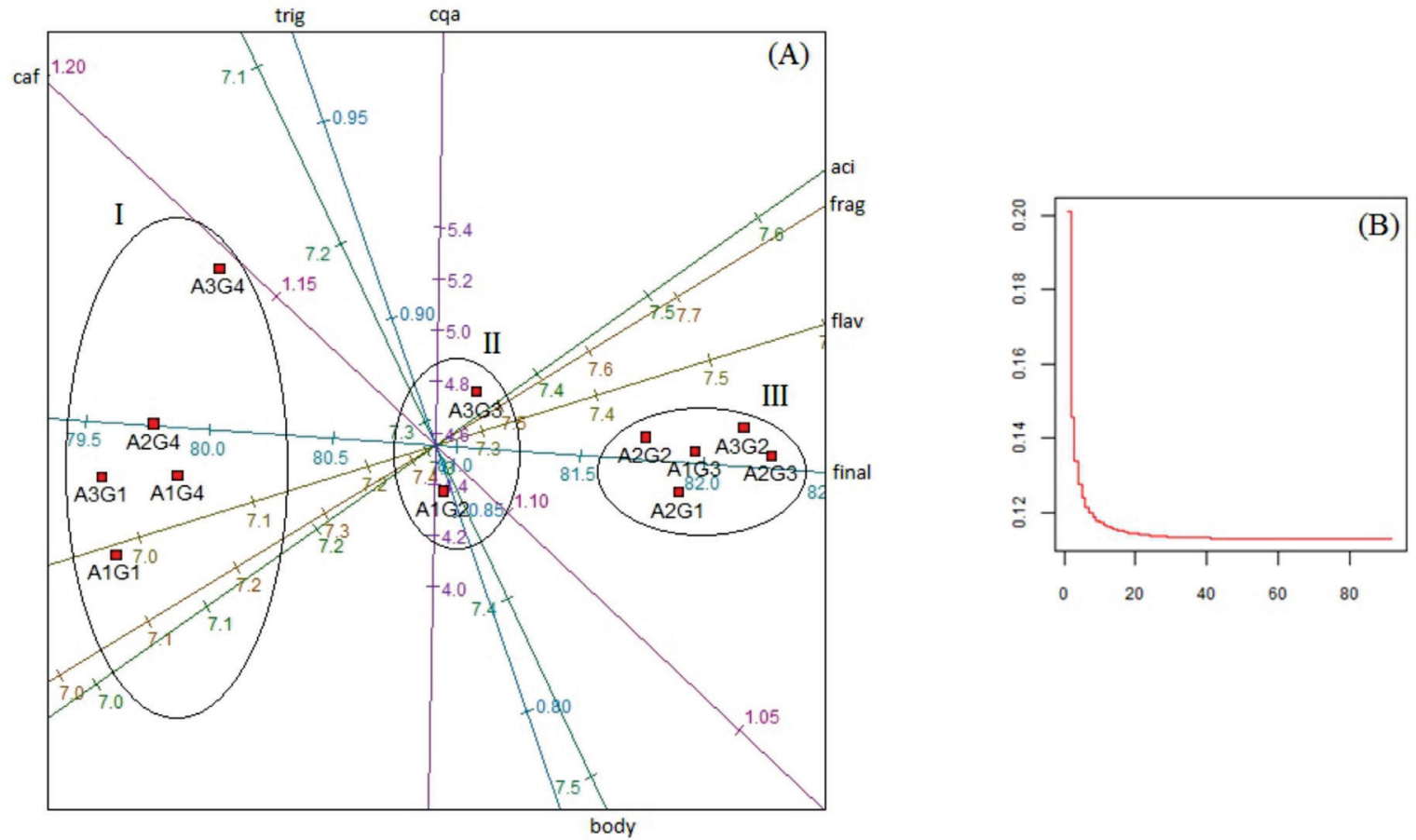

FIGURE 1 - (A) Biplot with multidimensional scaling of four genotypes (G) and three environments (A), for the sensory attributes and final sensory score evaluated. (B) Stressfunctiongenerated as a function of the interaction among factors. frag $=$ fragrance, flav $=$ flavor, aci $=$ acidity, final $=$ final sensory score, G1 $=$ Mundo Novo IAC 502/9, G2= Yellow Bourbon IAC J9, G3= YellowBourbon/SSP, G4= YellowBourbon/CM, A1= Lavras, A2= São Sebastião da Grama, A3= Santo Antônio do Amparo.

scores (group III) (Figure 1A).

Cultivar Mundo Novo (G1) is widely cultivated in Brazil, mainly due to its high yield (CARVALHO, MENDES, BARTHOLO, and CEREDA, 2006). However, it presented limitations in the production of specialty coffees, indicating that the quality of its beverage is dependent on environmental conditions where it is grown. The genotype Mundo Novo (G1) was sensorially highlighted only when grown in the most promising environment for the production of specialty coffees (A2).

When combined with genotypes Yellow Bourbon and Yellow Bourbon IAC J9, respectively A1G3 and A3G2, the environments Lavras and Santo Antônio do Amparo stood out in the sensory evaluation and allowed the production of flavored coffees, with intense acidity and fragrance, besides a high sensory quality. In this case, the interaction genotype and environment was crucial for the manifestation of flavors in coffees, emphasizing the contribution of Bourbon genotypes. These results confirm the high potential of genotypes G2 and G3 for the obtention of specialty coffees in different manufacturing environments. It is observed that genetic diversity is one of the factors that most contribute to the definition of Arabica coffee beverage quality (DESSALEGN et al., 2008; PEREIRA et al., 2010).Thus, it is believed that technological research and innovation programs that seek to increase the supply of specialty coffees should invest more in understanding gene expression in quality and supply of new genotypes able to produce coffee with diversity in flavor, even when grown under different conditions.

In study, the effects of processing, genotypes and production environment were evaluated on coffee quality (SALLA, 2009). A strong interference of genetic makeup was identified in flavor determination. Beverage quality of most genotypes and cultivars ranged as a function of environment and processing. However, some cultivars showed a better-quality beverage in any environment and processing, indicating high genetic stability for beverage quality (SALLA, 2009).

Table 5 shows the dissimilarity measure matrix among the twelve points of the interaction between genotypes and environments $\left(A_{x} G_{y}\right)$ for sensory and chemical variables of the transformed 
TABLE 5 - Dissimilarity matrix among the twelve points (interactions genotypes $\chi$ environments, $A_{x} G_{y}$ for sensory and chemical variables.

\begin{tabular}{ccccccccccccc}
\hline & A1G1 & A1G2 & A1G3 & A1G4 & A2G1 & A2G2 & A2G3 & A2G4 & A3G1 & A3G2 & A3G3 & A3G4 \\
\hline A1G1 & 0.000 & 1.429 & 2.501 & 0.508 & 2.419 & 2.305 & 2.821 & 0.521 & 0.377 & 2.714 & 1.670 & 1.248 \\
A1G2 & 1.429 & 0.000 & 1.097 & 1.194 & 1.022 & 0.891 & 1.410 & 1.254 & 1.437 & 1.307 & 0.450 & 1.335 \\
A1G3 & 2.501 & 1.097 & 0.000 & 2.246 & 0.204 & 0.248 & 0.334 & 2.296 & 2.482 & 0.254 & 0.965 & 2.169 \\
A1G4 & 0.508 & 1.194 & 2.246 & 0.000 & 2.194 & 2.042 & 2.563 & 0.348 & 0.535 & 2.459 & 1.351 & 0.854 \\
A2G1 & 2.419 & 1.022 & 0.204 & 2.194 & 0.000 & 0.291 & 0.443 & 2.238 & 2.414 & 0.358 & 0.947 & 2.154 \\
A2G2 & 2.305 & 0.891 & 0.248 & 2.042 & 0.291 & 0.000 & 0.539 & 2.095 & 2.283 & 0.443 & 0.778 & 1.986 \\
A2G3 & 2.821 & 1.410 & 0.334 & 2.563 & 0.443 & 0.539 & 0.000 & 2.616 & 2.803 & 0.188 & 1.274 & 2.467 \\
A2G4 & 0.521 & 1.254 & 2.296 & 0.348 & 2.238 & 2.095 & 2.616 & 0.000 & 0.340 & 2.495 & 1.383 & 0.774 \\
A3G1 & 0.377 & 1.437 & 2.482 & 0.535 & 2.414 & 2.283 & 2.803 & 0.340 & 0.000 & 2.686 & 1.610 & 1.051 \\
A3G2 & 2.714 & 1.307 & 0.254 & 2.459 & 0.358 & 0.443 & 0.188 & 2.495 & 2.686 & 0.000 & 1.156 & 2.346 \\
A3G3 & 1.670 & 0.450 & 0.965 & 1.351 & 0.947 & 0.778 & 1.274 & 1.383 & 1.610 & 1.156 & 0.000 & 1.215 \\
A3G4 & 1.248 & 1.335 & 2.169 & 0.854 & 2.154 & 1.986 & 2.467 & 0.774 & 1.051 & 2.346 & 1.215 & 0.000 \\
\hline G1=Mundo Novo IAC 502/9, G2= YellowBourbon IAC J9, G3=Yellow Bourbon/SSP, G4=Yellow Bourbon/CM, \\
A1=Lavras, A2= São Sebastião da Grama, A3= Santo Antônio do Amparo & & & & &
\end{tabular}

data matrix.

In the literature, there is extensive material aiming at the obtention of the correlation between chemical compounds (caffeine, trigonelline and 5-CQA) with the sensory coffee profile (BERTRAND ET AL., 2008; CAMPA ET AL., 2004; DUARTE, PEREIRA, AND FARAH, 2010; FARAH, MONTEIRO, CALADO, FRANCA, AND TRUGO, 2006; FRANCA, OLIVEIRA, MENDONÇA, AND SILVA, 2005).

The results obtained for caffeine, trigonelline and 5-CQA with multidimensional scaling of four genotypes and three environments for sensory attributes, final sensory score and chemical compounds evaluated, are shown in Figure 2. The results show a relationship between sensory characteristics and contents of chemical compounds in the differentiation of genotypes and environments.

In Figure 2, it is observed that the grouping of points obtained as a function of sensory attributes (Figure 1) was kept; the stress function (0.11) also indicates good model fit (Figure 2B).

The inclusion of chemical compounds allowed a greater distance from most points $\left(A_{x} G_{y}\right)$, represented by the increasing dissimilarity between them, according to Table 5 of dissimilarity. Comparatively, the highest dissimilarity occurred in the group with the lowest sensory scores.

The chemical compound 5-CQA showed the highest correlation with the yaxis and thus provided greater distance of points belonging to the same genotype. Considering these points regarding the interaction of genotype G4with three environments (A1G4, A2G4 and A3G4), it is found that the content of 5-CQA enabled an increase in point divergence, that is, it allowed a greater differentiation of environments A1, A2 and A3, when combined with this genotype. The highest 5-CQA contents were found in environment A3. For other genotypes, the same behavior was observed, with higher 5-CQA contents in environment A3, compared to environments A2 and A1.

Avelino et al. (2005) differentiated the environments Santa Maria de Dota and Orosi (Costa Rica) from the quantification of chemical compounds caffeine, trigoneline, chlorogenic acids and sucrose. The composition of chlorogenic acids and especially fatty acids, allowed the differentiation of environments Naranjal, Paraguaicito and Rosario, located in Colombia (BERTRAND et al., 2008).

However, among the chemical compounds, 5-CQA was the one that best distinguished the studied environments.

The content of trigoneline was not a good discriminator of the groups formed. However, in general, the content of trigoneline was lower in coffees that had higher final scores in the sensory evaluation (group III) (Figure 2A).

It is observed that the sensory characteristics were clearly represented along the $\mathrm{x}$ axis, while the chemical compounds 5-CQA and 

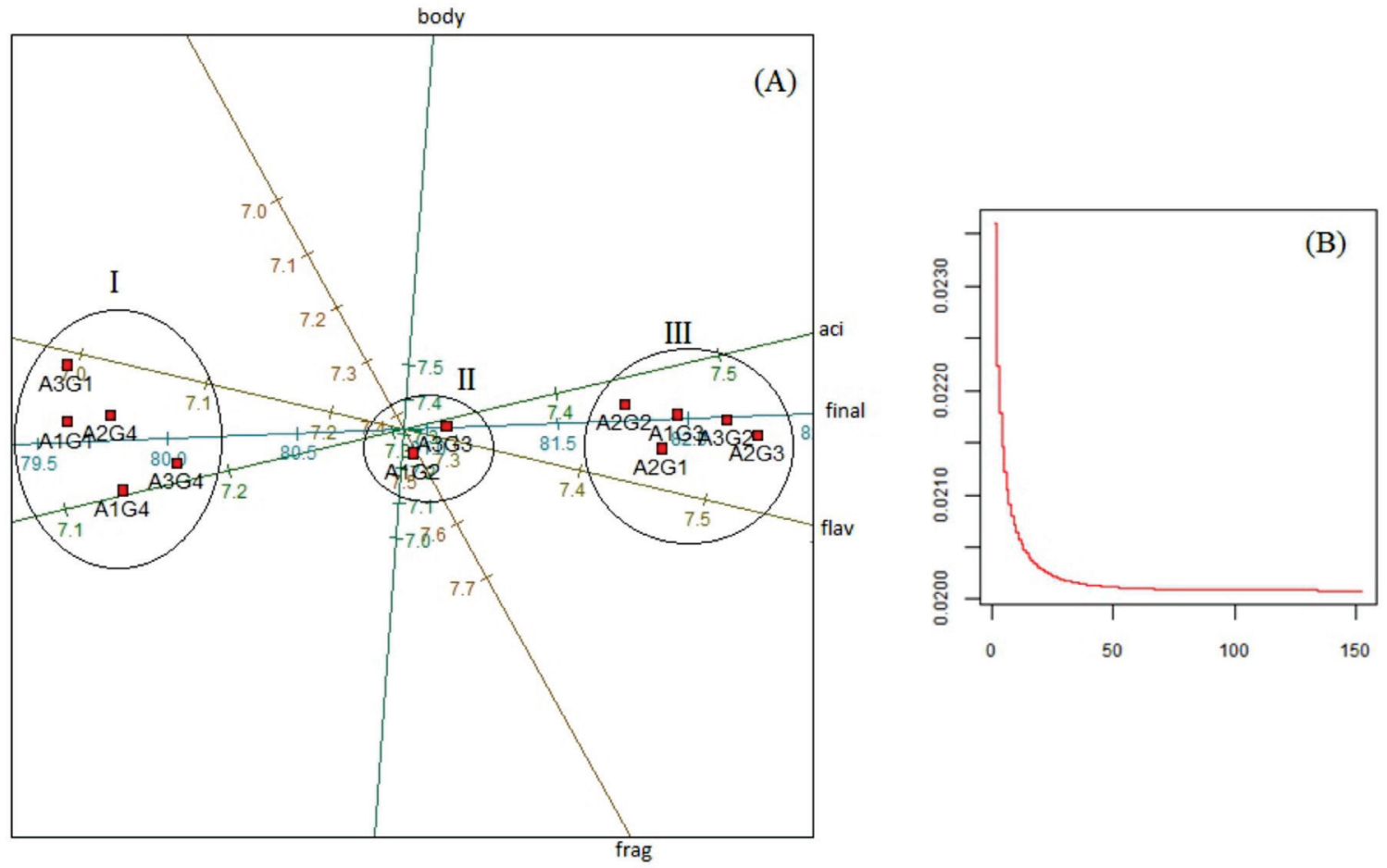

FIGURE 2 - (A) Biplot with multifunctional scaling of four genotypes (G) and three environments (A), for the sensory attributes, final sensory score and the chemical compounds evaluated. (B) Stress function generated as a function of the interaction among factors. frag $=$ fragrance, flav = flavor, aci $=$ acidity, final $=$ final sensory score, caf $=$ caffeine, trig = trigoneline, CQA = 5CQA, G1= Mundo Novo IAC 502/9, G2= Yellow Bourbon IAC J9, G3= Yellow Bourbon/SSP, G4= Yellow Bourbon/CM, A1= Lavras, A2= São Sebastião da Grama, A3= Santo Antônio do Amparo.

trigonelline were along the y axis (Figure 2A).

Avelino et al. (2005) also found that some chemical characteristics were largely independent of the sensory characteristics of the evaluated coffees, among them, the content of chlorogenic acids and trigoneline.

On the other hand, caffeine content correlated with the separation of groups I and III, that is, it allowed the differentiation of coffees $\left(A_{x} G_{y}\right)$ with lower and higher final sensory scores. Coffees belonging to group III showed the lowest caffeine contents and the highest sensory scores, while those belonging to group I had higher caffeine contents and lower sensory scores.

Dessalegn et al. (2008) also observed negative and significant associations between caffeine content and sensory attributes of coffee, such as acidity, body and flavor. The same authors also related low caffeine contents with physical characteristics desirable in green coffee beans, such as size, shape and uniformity. It is believed that caffeine biosynthesis and accumulation in green beans can be more pronounced during stress than in favorable conditions. Ribeiro et al.(2011) related the content of caffeine and chlorogenic acids to the attribute bitterness.

Unlike what happened to group I, points $\mathrm{A} 3 \mathrm{G} 2, \mathrm{~A} 2 \mathrm{G} 3, \mathrm{~A} 1 \mathrm{G} 3$ and A2G2 (group III) increased their similarity with the inclusion of chemical variables. Thus, it is observed that coffees with lower final sensory scores (group I) have higher chemical variability than coffees that have higher final sensory scores (group III) (Figure 2A).

The relationship between the content of caffeine, trigoneline and 5-CQA and sensory coffee quality is still quite controversial. In this study and under the analyzed conditions, only caffeine content was a coffee discriminator for beverage quality, while 5-CQA, an environment discriminator.

\section{CONCLUSIONS}

São Sebastião da Grama (A2) is the most promising environment for the production of specialty coffees. Regardless of culture environment, the genotype Yellow Bourbon (G4) 
is not indicated for the production of specialty coffees.In a favorable environment, cultivar Mundo Novo IAC 502/9 produces quality coffees. Lavras and Santo Antônio do Amparo produce quality coffees, depending on the cultivated genotype. Genotypes Yellow Bourbon IAC J9 and Yellow Bourbon (G3) are the most suitable for the production of specialty coffees. Caffeine content allowed to differentiate coffees regarding beverage quality. Coffees with superior quality have lower caffeine contents. The content of 5-CQA allowed to differentiate environments.

\section{ACKNOWLEDGEMENTS}

The authors are gratefulto the Conselho Nacional de Desenvolvimento Científico e Tecnológico $(\mathrm{CNPq})$, the Fundação de Amparo à Pesquisa do Estado de Minas Gerais (FAPEMIG), the Coordenação de Aperfeiçoamento de Pessoal de Nível Superior (CAPES), the Empresa de Pesquisa Agropecuária de Minas Gerais (EPAMIG), the Instituto Agronômico (IAC) and the Instituto Nacional de Ciência e Tecnologia do Café (INCT/Café).

\section{REFERENCES}

ALVES, H. M. R.; VOLPATO, M. M. L.; VIEIRA, T. G. C.; BORÉM, F. M.; BARBOSA, J. N. Características ambientais e qualidade da bebida dos cafés do estado de Minas Gerais. Informe Agropecuário, Belo Horizonte, v. 32, n. 261, p. 18-29, 2011.

AVELINO, J.; BARBOZA, B.; ARAYA, J. C.; et al. Effects of slope exposure, altitude and yield on coffee quality in two altitudeterroirs of Costa Rica, Orosi and Santa María de Dota. Journal of the Science of Food and Agriculture, London, v. 85, n. 11, p. 1869-1876, 2005.

BERTRAND, B.; VAAST, P.; ALPIZAR, E.; et al. Comparison of bean biochemical composition and beverage quality of Arabica hybrids involving Sudanese-Ethiopian origins with traditional varieties at various elevations in Central America. Tree physiology, Victoria, v. 26, n. 9, p. 1239-48, 2006.

BERTRAND, B.; VILLARREAL, D.; LAFFARGUE, A.; et al. Comparison of the effectiveness of fatty acids, chlorogenic acids, and elements for the chemometric discrimination of coffee (Coffea arabica L.) varieties and growing origins. Journal of agricultural and food chemistry, Easton, v. 56, n. 6, p. 2273-2280, 2008.

BORÉM, F. M.; ANDRADE, E. T de.; ISQUIERDO, E. P. Coffee Drying. In Handbook of Coffee Post-
Harvest Technology. UFLA ed. Lavras, 2014.

CAMARGO, M. B. P. DE. The impact of climatic variability and climate change on Arabic Coffee crop in Brazil. Bragantia, Campinas, v. 69, n. 1, p. 239-247, 2010.

CAMPA, C.; BALLESTER, J. .; DOULBEAU, S.; et al. Trigonelline and sucrose diversity in wild Coffea species. Food Chemistry, Oxford, v. 88, n. 1, p. 39-43, 2004.

CARVALHO, G. R.; MENDES, A. N. G.; BARTHOLO, G. F.; CEREDA, G. J. Comportamento de progênies cafeeiro cultivar Mundo Novo. Ciência e Agrotecnologia, Lavras, v. 30, n. 5, p. 853-860, 2006.

COX, T. F. .; COX, M. A. . Muldimensional scaling. Washington: Boca Raton, 2001.

DAL MOLIN, R. N.; ANDREOTTI, M.; REIS, A. R. DOS; et al. Caracterização física e sensorial do café produzido nas condições topoclimáticas de Jesuitas , Paraná. Acta Scientiarum. Agronomy, Maringá, v. 30, n. 3, p. 353-358, 2008.

DECAZY, F.; AVELINO, J.; GUYOT, B.; et al. Quality of Different Honduran Coffees in Relation to Several Environments. Journal of Food Science, Champaign v. 68, n. 7, p. 2356-2361, 2003.

DESSALEGN, Y.; LABUSCHAGNE, M. T.; OSTHOFF, G.; HERSELMAN, L. Genetic diversity and correlation of bean caffeine content with cup quality and green bean physical characteristics in coffee ( Coffea arabica L .). Journal of the science of food and agriculture, London, v. 88, n. 10, p. 17261730, 2008.

DUARTE, G. S.; PEREIRA, A. A.; FARAH, A. Chlorogenic acids and other relevant compounds in Brazilian coffees processed by semi-dry and wet postharvesting methods. Food Chemistry, Oxford, v. 118, n. 3, p. 851-855, 2010.

FARAH, A.; MONTEIRO, M. C.; CALADO, V.; FRANCA, A. S.; TRUGO, L. C. Correlation between cup quality and chemical attributes of Brazilian coffee. Food Chemistry, Oxford, v. 98, n. 2, p. 373-380, 2006.

FERREIRA, A. D.; CARVALHO, G. R.; REZENDE, J. C de.; BOTELHO, C. E.; REZENDE, R. M.. CARVALHO, A. M de. Desempenho agronômico de seleções de café Bourbon Vermelho e Bourbon 
Amarelo de diferentes origens. Pesquisa Agropecuária Brasileira, Brasília, v.48, n. 4, p. 388-394, 2013.

FERREIRA, A. D.; MENDES, A. N. G.; CARVALHO, G. R.; et al. Análise sensorial de diferentes genótipos de cafeeiros bourbon. Interciencia, Catanduva, v. 37, n. 5, p. 390-394, 2012.

FIGUEIREDO, L. P.; BORÉM, F. M.; CIRILLO, M. Â.; et al. The Potential for High Quality Bourbon Coffees From Different Environments. Journal of Agricultural Science,

Ottawa, v. 5, n. 10, p. 87-98, 2013.

FIGUEIREDO, L. P.; BORÉM, F. M.; RIBEIRO, F. $\mathrm{C}$; ; et al. Fatty acid profiles and parameters of quality of specialty coffees produced in different Brazilian regions. African Journal of Agricultural Research, Nairobi v. 10, n. 35, p. 3484-3493, 2015.

FIGUEIREDO, L. P. Perfil sensorial e químico de genótipos de cafeeiro Bourbon de diferentes origens geográficas. 2010. 81p. Dissertação (Mestrado em Ciência dos Alimentos) - Universidade Federal de Lavras, Lavras, 2010.

FRANCA, A. S.; OLIVEIRA, L. S.; MENDONÇA, J. C. F.; SILVA, X. A. Food Chemistry Physical and chemical attributes of defective crude and roasted coffee beans. Food Chemistry, Oxford, v. 90, p. 8994, 2005.

GIOMO, G. S.; BORÉM, F. M. Cafés especiais no Brasil: opção pela qualidade. Informe Agropecuário, Belo Horizonte, v. 32, n. 261, p. 7-16, 2011.

GUYOT, B.; GUEUlE, D.; MANEZ, J. C.; et al. Influence de l'altitude et de l'ombrage sur la qualité des cafés Arabica. Plantations, recherche, développement, Paris, p. 272-283, 1996.
KY, C.; BARRE, P.; NOIROT, M. Genetic investigations on the caffeine and chlorogenic acid relationship in an interspecific cross between Coffea liberica dewevrei and C . pseudozanguebariae. Tree Genetics \& Genomes, Davis, p. 1043-1049, 2013.

LINGLE, T. R. The coffee cupper's handbook: systematic guide to the sensory evaluation of coffee's flavor. 4. ed. ed. Califórnia: Long Beach: Specialty Coffee Association of America, 2011.

PEREIRA, M. C.; CHALFOUN, S. M.; CARVALHO, G. R. DE; SAVIAN, T. V. Multivariate analysis of sensory characteristics of coffee grains ( Coffea arabica L.) in the region of upper Paranaíba. Acta Scientiarum. Agronomy, Maringá, v. 32, n. 4, p. 635-641, 2010.

PERRONE, D.; DONANGELO, C. M.; FARAH, A. Fast simultaneous analysis of caffeine, trigonelline , nicotinic acid and sucrose in coffee by liquid chromatography - mass spectrometry. Food Chemistry, Oxford, v. 110, p. 1030-1035, 2008.

R DEVELOPMENT CORE TEAM. R: A language and environment for statistical computing. ., 2012.

RIBEIRO, J. S.; FERREIRA, M. M. C.; SALVA, T. J. G. Chemometric models for the quantitative descriptive sensory analysis of Arabica coffee beverages using near infrared spectroscopy. Talanta, London, v. 83, n. 5, p. 1352-8, 2011.

SALLA, M. H. Influence of genotype, location and processing methods on the quality of coffee (Coffea arabica L.), Hawassa University, Awassa, 2009.

VILLARREAL, D.; LAFFARGUE, A.; POSADA, H.; et al. Genotypic and environmental effects on coffee (Coffea arabica L.) bean fatty acid profile: impact on variety and origin chemometric determination. Journal 